\title{
Serviceberry Cultivars Tested as Street Trees: Second Report
}

\author{
Henry D. Gerhold
}

\begin{abstract}
Through the Municipal Tree Restoration Program, cooperators planted eight serviceberry (Amelanchier spp.) cultivars in 15 communities for evaluation as street trees, typically comparing two in each community. Standardized measurements in years $1,2,3,6,9$, and 12 revealed differences in trunk diameter, height, crown width, and health of foliage and branches. Among the four cultivars that have been tested most extensively, the main difference is that Cumulus ${ }^{\circledR}$ and Robin Hill are much taller in the twelfth year than Tradition ${ }^{\circledR}$ and Autumn Brilliance ${ }^{\circledR}$. 'Cole's Select', 'Princess Diana', Reflection ${ }^{\mathrm{TM}}$, and Spring Glory ${ }^{\circledR}$ also have been performing well for 6 to 10 years, but they have been tested at just one or two locations. Survival, growth, and health have been superior on more spacious sites, but with proper care, serviceberry cultivars can do well even along downtown streets. All eight of these cultivars are appropriate for planting under overhead wires.
\end{abstract}

Key Words. Amelanchier; performance testing; serviceberry cultivars; street tree evaluation.

In 1989, the Municipal Tree Restoration Program (MTRP) started evaluating serviceberry (Amelanchier spp.) cultivars as street trees. MTRP encourages municipalities to improve their tree programs through demonstration plantings of free trees and, through research, provides helpful information for selecting species and cultivars that are compatible with utility wires. A previous report (Gerhold 1999) indicated the five cultivars that had been evaluated by then, Autumn Brilliance ${ }^{\circledR}$, Cumulus ${ }^{\circledR}$, 'Princess Diana', 'Robin Hill', and Tradition ${ }^{\circledR}$, generally had healthy foliage and grew well. Autumn Brilliance ${ }^{\circledR}$ was broader but not as tall as the others at that time and had healthier foliage. All had pleasing characteristics, and their structure was conducive to pruning, which would give clearance for pedestrians and vehicles.

Descriptions of the cultivars being tested, and many others, appear in Dirr (1998), Gerhold et al. (2001), and Jacobson (1996).

\section{MATERIALS AND METHODS}

\section{Plants and Experimental Design}

Cooperators planted the serviceberry cultivars during 1989 to 1999 in 14 Pennsylvania, U.S. communities (Bedford, Blairsville, Delaware Water Gap, Eagles Mere, Genesee, Laporte, Meadville, Orrstown, Reading, Tioga, Union City, Warren, Washington, and Williamsport) and one in Waverly, New York. Representatives of the communities chose several planting sites in each municipality with the advice of utility foresters, service foresters in the Bureau of Forestry, or Penn State extension urban foresters. Characterization of the soils was not attempted, because urban soils are so highly variable that they cannot be put into a normal classification system. The experimental plots represented a variety of randomly sampled site conditions within each community, enabling valid statistical comparisons between the cultivars in a community by analyzing variation between cultivars and among plots.

Each test planting in a community consisted of two cultivars, except for one in Waverly, New York, which had a single cul- tivar; two others were planted there a year later. The two cultivars in a community were alternated within each plot. The number of plots in a community varied according to spaces that were available and could accommodate at least four trees. Typically there were four to ten plots that contained four to 16 trees each resulting in a total of 48 to 50 trees. All of the trees being tested were planted along streets and under electric conductors. The local utility company arranged for the removal of any large trees that interfered with utility lines, thus making space for planting in some plots.

\section{Plant Materials}

Eight serviceberry cultivars were tested: Autumn Brilliance ${ }^{\circledR}$, 'Cole's Select', Cumulus ${ }^{\circledR}$, 'Princess Diana', Reflection ${ }^{\mathrm{TM}}$, 'Robin Hill', Spring Glory ${ }^{\circledR}$, and Tradition ${ }^{\circledR}$. The species names of these cultivars are inconsistent in the nursery trade and the literature and may include Amelanchier arborea, A. canadensis, A. laevis, and A. $\times$ grandiflora.

The test trees came from several nurseries as balled and burlapped stock, and when nursery stock was dug, the longer roots extending beyond the root ball were severed. The same nursery always supplied the two cultivars for a community. When the trees were planted, average calipers $(15 \mathrm{~cm}$ [6 in] above the ground) ranged from 2.6 to $4.7 \mathrm{~cm}$ (1.04 to $1.88 \mathrm{in}$ ) and average heights from 2.8 to $4.1 \mathrm{~m}$ (9.2 to $13.5 \mathrm{ft})$. The wide range in heights and calipers presumably could be explained by genetic differences among cultivars and cultural differences among the nurseries that supplied the trees.

\section{Measurements and Analysis}

Trained cooperators inspected and measured the trees soon after planting, then annually during the first 3 years, and at 3-year intervals afterward. During September or October, a service forester or extension urban forester, using standardized procedures, measured tree height, trunk diameter at breast height, and crown width; and classified the health of foliage, branches, and trunk separately. The health of foliage and branches was estimated 
according to the percentage injured using a five-point scale: $1=$ 65 to $100,2=45$ to $60,3=25$ to $40,4=5$ to 20 , and $5=$ less than 5 . The scale for trunk injuries was $1=$ tree dead, $2=$ severe injuries, $3=$ moderate, $4=$ slight, and $5=$ no injuries. Causes of injuries such as diseases, insects, drought, or mechanical damage were identified when possible and recorded.

An analysis of variance (using MINITAB's [State College, PA] general linear model) of quantitative data collected in a given year calculated means and determined statistical differences between the cultivars and among plots in each community at the $5 \%$ level of probability. Each test location in every year constituted a separate experiment with plots providing replication within a community. These results, along with comments provided by cooperators, were used to characterize performance of the cultivars.

\section{RESULTS AND DISCUSSION}

Survival rates were best at Genesee, being $100 \%$ for both cultivars through year 12; also at Laporte, at $100 \%$ when last measured in year nine; and at Meadville, where only one tree had been lost through the ninth year. There were wide tree lawns at all of these three locations. At most other locations, survival started declining in the first 3 years, commonly being reduced to $60 \%$ to $88 \%$ in year 12 and even to $48 \%$ in the worst case. At Delaware Water Gap, one-third of the trees had to be replaced after the first year because roots had been pruned excessively when the trees were lifted at the nursery. Investigation revealed that the tree spade had not been centered over the root systems, which were not symmetric. Despite the mortality rates, the serviceberries proved to be rather resilient even in downtown situations. For example, survival of the two cultivars was $73 \%$ and $80 \%$ in Bedford, where nearly all plots had just 0.6 to $0.9 \mathrm{~m} \mathrm{(2}$ to $3 \mathrm{ft}$ ) between the curbs and sidewalks.

Health ratings of the foliage ( 2.8 to 4.7$)$ and branches $(3.5$ to 5.0) were similar to those of crabapple cultivars (Gerhold 2007). The foliage was injured more than $40 \%$ in only four of 31 cases, and in 14 cases, foliage injury was below $20 \%$ when evaluated late in the growing season. Differences between cultivars in foliage health were significant in only two of 15 comparisons; in both of these, Autumn Brilliance ${ }^{\circledR}$ was superior to Cumulus ${ }^{\circledR}$. Injuries to trunks were infrequent and slight for all cultivars.

The principal differences among cultivars were in their dimensions (Table 1). Average 12-year heights of Cumulus ${ }^{\circledR}(5.5$ to $7.3 \mathrm{~m}$ [18.2 to $24.1 \mathrm{ft}$ ) ) and 'Robin Hill' (5.5 to $6.8 \mathrm{~m} \mathrm{[18.2}$ to $22.4 \mathrm{ft}$ ]) at various locations were greater than heights of Tradition ${ }^{\circledR}$ (3.7 to $5.3 \mathrm{~m}$ [12.2 to $\left.17.5 \mathrm{ft}\right]$ ) and Autumn Brilliance $^{\circledR}$ (3.9 to $5 \mathrm{~m}$ [12.9 to $\left.\left.16.5 \mathrm{ft}\right]\right)$. Trunk diameters showed similar relationships. Crown widths of Cumulus ${ }^{\circledR}$ (3.8 to $4.6 \mathrm{~m}$ [12.5 to $15.2 \mathrm{ft}$ ]), 'Robin Hill' (2.9 to $4.9 \mathrm{~m}$ [9.6 to $16.2 \mathrm{ft}$ ), Tradition ${ }^{\circledR}$ (3 to $4.5 \mathrm{~m}$ [9.9 to $\left.14.9 \mathrm{ft}\right]$ ), and Autumn Brilliance ${ }^{\circledR}$ (3.7 to $4.9 \mathrm{~m}$ [12.2 to $16.2 \mathrm{ft}]$ ) do not exhibit the same pattern, although there were significant differences at four locations.

The tests of 'Cole's Select', 'Princess Diana', Reflection ${ }^{\mathrm{TM}}$, and Spring Glory ${ }^{\circledR}$ also are promising, although they have not been tested as extensively. 'Cole's Select' might be the same cultivar as Autumn Brilliance ${ }^{\circledR}$ according to the nurseryman where it was grown; no significant differences between these two have been found in the tests so far. 'Princess Diana' in the ninth year was also similar to Autumn Brilliance ${ }^{\circledR}$. Reflection compared well with Tradition ${ }^{\circledR}$ but had a narrower crown. Spring Glory ${ }^{\circledR}$ had smaller dimensions than 'Reflection'.

The fastest growth rates of the four cultivars for which the most extensive data are available illustrate expectations for the future. The greatest 12-year heights attained by the cultivars at various locations (Figure 1) were Cumulus ${ }^{\circledR}$ at Genesee $(7.3 \mathrm{~m}$ [24.1 ft]), 'Robin Hill' at Delaware Water Gap (6.8 m [22.4 ft]), Tradition ${ }^{\circledR}$ at Warren $\left(5.1 \mathrm{~m}\right.$ [16.8 ft]), and Autumn Brilliance ${ }^{\circledR}$ at Genesee $\left(5 \mathrm{~m}\right.$ [16.5 ft]). Only Cumulus ${ }^{\circledR}$ and Autumn Brilliance ${ }^{\circledR}$ are directly comparable being at the same location. The rate of height growth of the two taller cultivars had not slowed down much or at all by the twelfth year and was approaching some overhead electric utility wires. The projected heights of Tradition ${ }^{\circledR}$ and Autumn Brilliance ${ }^{\circledR}$ would not reach $7 \mathrm{~m}$ (23.1 ft) for another 12 years if at all. None of the heights or widths in

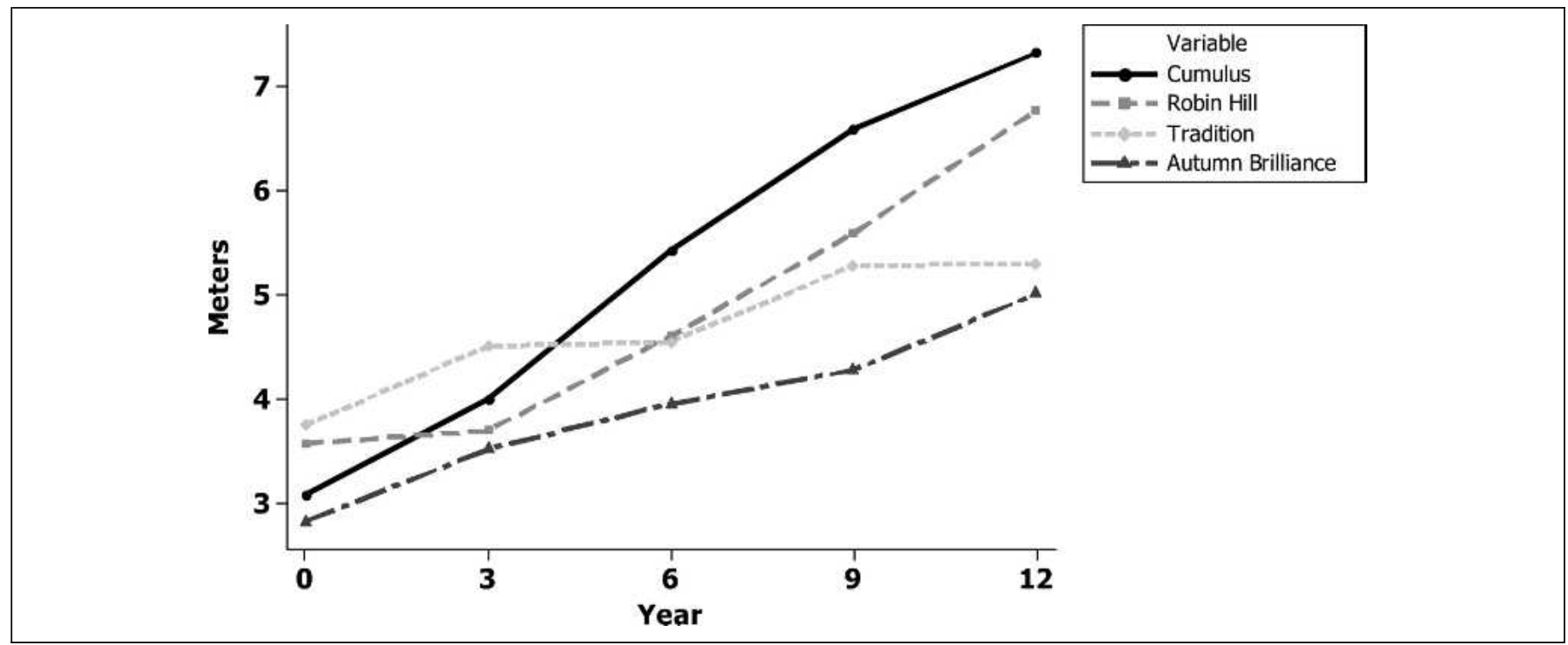

Figure 1. Serviceberry cultivar heights at various locations: Cumulus at Genesee, 'Robin Hill' at Delaware Water Gap, Tradition at Warren, and Autumn Brilliance at Genesee. 
Table 1. Size and health ratings of serviceberry cultivars planted as street trees with two cultivars paired at most locations.

\begin{tabular}{|c|c|c|c|c|c|c|c|}
\hline Cultivar/abbrev. & $\begin{array}{l}\text { Paired } \\
\text { cultivar }\end{array}$ & Year & $\begin{array}{l}\text { Diam } \\
(\mathrm{cm})\end{array}$ & $\begin{array}{l}\mathrm{Ht} \\
(\mathrm{m})\end{array}$ & $\begin{array}{l}\text { Width } \\
\text { (m) }\end{array}$ & $\begin{array}{l}\text { Foliage } \\
(1 \text { to } 5)\end{array}$ & $\begin{array}{l}\text { Branches } \\
\text { (1 to 5) }\end{array}$ \\
\hline Autumn Brilliance ${ }^{\circledR / A B}$ & $\mathrm{Cu}$ & 12 & $8.9^{\mathrm{y}}$ & $5.0^{\mathrm{y}}$ & $4.3^{\mathrm{x}}$ & $4.1^{\mathrm{x}}$ & 4.9 \\
\hline Autumn Brilliance ${ }^{\circledR}$ & $\operatorname{Tr}$ & 12 & $6.3^{\mathrm{y}}$ & $4.1^{\mathrm{y}}$ & 3.7 & 4.7 & 4.7 \\
\hline Autumn Brilliance ${ }^{\circledR}$ & $\operatorname{Tr}$ & 12 & 8.5 & $4.7^{\mathrm{x}}$ & $3.8^{\mathrm{x}}$ & 3.4 & 3.5 \\
\hline Autumn Brilliance ${ }^{\circledR}$ & $\operatorname{Tr}$ & 12 & 9.6 & 4.9 & 4.9 & 3.3 & 4.3 \\
\hline Autumn Brilliance ${ }^{\circledR}$ & $\mathrm{Cu}$ & 12 & $8.8^{\mathrm{y}}$ & $3.9^{y}$ & 4.1 & $4.7^{\mathrm{x}}$ & 4.9 \\
\hline Autumn Brilliance ${ }^{\circledR}$ & PD & 9 & 7.9 & 4.6 & 4.1 & 4.6 & 4.2 \\
\hline Autumn Brilliance ${ }^{\circledR}$ & $\mathrm{CS}$ & 7 & 5.0 & 4.0 & 3.1 & 4.4 & 4.8 \\
\hline Autumn Brilliance ${ }^{\circledR}$ & $\mathrm{CS}$ & 6 & 4.5 & 4.1 & 2.2 & 4.2 & 4.7 \\
\hline Cole's Select/CS & $\mathrm{AB}$ & 7 & 5.5 & 4.1 & 3.1 & 4.5 & 5.0 \\
\hline Cole's Select & $\mathrm{AB}$ & 6 & 4.6 & 4.1 & 2.4 & 4.3 & 4.7 \\
\hline Cumulus ${ }^{\circledR} / \mathrm{Cu}$ & RH & 12 & 11.6 & 5.5 & 2.9 & 4.5 & 4.7 \\
\hline Cumulus ${ }^{\circledR}$ & $\mathrm{AB}$ & 12 & $11.9^{\mathrm{x}}$ & $7.3^{\mathrm{x}}$ & $3.8^{\mathrm{y}}$ & $2.8^{\mathrm{y}}$ & 4.9 \\
\hline Cumulus ${ }^{\circledR}$ & RH & 11 & 9.3 & 5.6 & - & 4.0 & 4.3 \\
\hline Cumulus ${ }^{\circledR}$ & RH & 12 & 9.1 & 6.3 & 4.6 & 3.9 & 4.5 \\
\hline Cumulus ${ }^{\circledR}$ & RH & 12 & 12.8 & $7.2^{\mathrm{x}}$ & $4.0^{\mathrm{y}}$ & 3.5 & 4.6 \\
\hline Cumulus ${ }^{\circledR}$ & $\mathrm{AB}$ & 12 & $13.6^{\mathrm{x}}$ & $6.4^{\mathrm{x}}$ & 4.4 & $4.2^{\mathrm{y}}$ & 4.9 \\
\hline Cumulus ${ }^{\circledR}$ & RH & 9 & 12.0 & $5.5^{\mathrm{y}}$ & 5.0 & 4.2 & 4.9 \\
\hline Princess Diana/PD & $\mathrm{AB}$ & 9 & 8.0 & 4.4 & 4.0 & 4.5 & 4.4 \\
\hline Reflection $^{\mathrm{TM}} / \mathrm{Re}$ & $\operatorname{Tr}$ & 10 & 8.9 & 4.8 & $3.1^{\mathrm{y}}$ & 4.0 & 4.5 \\
\hline Reflection $^{\mathrm{TM}}$ & SG & 9 & 7.9 & 4.3 & 3.0 & 4.3 & 4.9 \\
\hline Robin Hill/RH & $\mathrm{Cu}$ & 12 & 10.9 & 5.5 & 2.9 & 4.5 & 4.6 \\
\hline Robin Hill & $\mathrm{Cu}$ & 11 & 9.7 & 5.6 & - & 4.1 & 4.3 \\
\hline Robin Hill & $\mathrm{Cu}$ & 12 & 10.3 & 6.8 & 4.7 & 3.9 & 4.7 \\
\hline Robin Hill & $\mathrm{Cu}$ & 12 & 12.5 & $6.0^{\mathrm{y}}$ & $4.7^{\mathrm{x}}$ & 3.6 & 4.4 \\
\hline Robin Hill & $\mathrm{Cu}$ & 9 & 13.5 & $6.8^{\mathrm{x}}$ & 4.9 & 4.2 & 4.9 \\
\hline Spring Glory ${ }^{\circledR} / \mathrm{SG}$ & $\operatorname{Re}$ & 9 & 7.5 & 4.0 & 2.7 & 4.2 & 5.0 \\
\hline Tradition ${ }^{\circledR} / \operatorname{Tr}$ & None & 12 & 8.2 & 4.4 & 3.2 & 3.9 & 4.2 \\
\hline Tradition ${ }^{\circledR}$ & $\mathrm{AB}$ & 12 & $8.2^{\mathrm{x}}$ & $5.3^{\mathrm{x}}$ & 3.8 & 4.6 & 4.7 \\
\hline Tradition ${ }^{\circledR}$ & $\mathrm{AB}$ & 12 & 7.4 & $3.7^{\mathrm{y}}$ & $3.0^{\mathrm{y}}$ & 3.5 & 3.6 \\
\hline Tradition $^{\circledR}$ & $\mathrm{AB}$ & 12 & 9.8 & 5.1 & 4.5 & 2.9 & 4.4 \\
\hline Tradition ${ }^{\circledR}$ & $\mathrm{Re}$ & 10 & 8.4 & 4.5 & $4.0^{\mathrm{x}}$ & 4.1 & 4.3 \\
\hline
\end{tabular}

${ }^{\mathrm{z}}$ Average trunk diameter, tree height, and crown width are in the most advanced year; foliage health and branch health ratings are averaged over all years: 1, 2, 3, 6,9 , and 12 in most cases.

${ }^{y}$ Significantly smaller at $95 \%$ level than corresponding value of the paired cultivar. Foliage and branch health ratings: $1=65 \%$ to $100 \%$ of leaves or branches exhibit injury, $2=45 \%$ to $60 \%, 3=25 \%$ to $40 \%, 4=5 \%$ to $20 \%, 5=$ less than $5 \%$.

${ }^{\mathrm{x}}$ Significantly greater at $95 \%$ level than corresponding value of the paired cultivar.

the twelfth year has yet attained the dimensions of mature trees given by Dirr (1998), but it appears the faster-growing cultivars will be as tall when they mature or may even exceed Dirr's figures.

A few complaints have been registered about stains caused by the fruits when they fall on sidewalks. Birds like the berries, and those that fall on walkways during the summer can be swept aside.

\section{CONCLUSIONS}

All eight of the serviceberry cultivars being tested are performing well in urban settings. Autumn Brilliance ${ }^{\circledR}$, Cumulus ${ }^{\circledR}$, 'Robin Hill', and Tradition ${ }^{\circledR}$ have been tested more extensively, so these can be selected more confidently. 'Cole's Select', 'Princess Diana', Reflection ${ }^{\mathrm{TM}}$, and Spring Glory ${ }^{\circledR}$ have been tested only at one or two locations for 6 to 10 years. The growth and health of the eight cultivars have been better in more spacious settings and away from urban stresses. However, they have also performed well along downtown streets where spaces between curbs and sidewalks were only $1 \mathrm{~m}(3.3 \mathrm{ft})$ wide or less.

For plantings under overhead wires, Autumn Brilliance ${ }^{\circledR}$ and Tradition ${ }^{\circledR}$ are less likely to interfere for at least 24 years. $\mathrm{Cu}$ mulus ${ }^{\circledR}$ and 'Robin Hill' have nearly reached a height of $8 \mathrm{~m}$ $(26.4 \mathrm{ft})$ in 12 years on the most favorable sites.

Acknowledgments. Financial support for the Municipal Tree Restoration Program was provided by Allegheny Energy, Asplundh Tree Expert Company, Baltimore Gas \& Electric Company, Bartlett Tree Expert Company, Duquesne Light Company, First Energy Company, Hazlett Tree Service, PECO Energy Company, PPL Electric Utilities, and UGI Utilities. Foresters of the Pennsylvania Bureau of Forestry and Extension Urban Foresters of Penn State University assisted with community liaison and tree measurements.

\section{LITERATURE CITED}

Dirr, M.A. 1998. Manual of Woody Landscape Plants. Stipes Publishing, Champaign, IL. 1187 pp.

Gerhold, H.D. 1999. Serviceberry cultivars tested as street trees: Initial results. Journal of Arboriculture 25:189-192.

- 2007. Crabapple cultivars tested as street trees: Third report. Journal of Arboriculture 33:176-181.

Gerhold, H.D., N.L. Lacasse, and W.N. Wandell (Eds.). 2001. Landscape Tree Factsheets. Penn State College of Agricultural Sciences, University Park, PA. 452 pp.

Jacobson, A.L. 1996. North American Landscape Trees. Ten Speed Press, Berkeley, CA.

Henry D. Gerhold

Professor of Forest Genetics

Pennsylvania State University

School of Forest Resources

333 Forest Resources Building

University Park, PA 16802, U.S.

hdg@psu.edu

Résumé. Avec le Programme municipal de restauration des arbres, des coopérateurs ont planté huit cultivars différents d'amélanchiers (Amelanchier) dans 15 communautés pour évaluer ces arbres en tant qu'arbres de rues, et ce en comparant deux espèces par communauté. Des mesures standardisées prises aux années 1, 2, 3, 6, 9 et 12 ont révélées des différences dans le diamètre du tronc, la hauteur, la largeur de la couronne ainsi que la santé du feuillage et des branches. Parmi les quatre cultivars qui ont été testés plus intensément, la différence principale est que Cumulus ${ }^{\circledR}$ et Robin Hill étaient plus grands durant les 12 années que Tradition ${ }^{\circledR}$ et Autumn Brilliance ${ }^{\circledR}$. 'Coles Select', 'Princess Diana', Reflection ${ }^{\mathrm{TM}}$ et Spring Glory ${ }^{\circledR}$ ont aussi bien performés de six à dix ans, mais ils ont été testés seulement à un ou deux endroits. Le taux de survie, le taux de croissance et la santé étaient supérieurs dans les sites plus spacieux, mais ces cultivars d'amélanchiers entretenus de manière appropriée peuvent aussi bien se comporter le long des rues d'un centre-ville. Tous ces huit cultivars sont appropriés pour la plantation sous des réseaux électriques.

Zusammenfassung. Mit dem kommunalen Baumpflanzprogramm pflanzten die Kooperateure acht Felsenbirnen-Kultivare in fünfzehn Kommunen, um sie als Straßenbäume zu testen und verglichen jeweils zwei in jeder Kommune. Standardisierte Messungen in den Jahren 1, 2, 3, 6, 9 und 12 und 12 ergaben Unterschiede in Durchmesser, Höhe, Kronenbreite, Blatt- und Astgesundheit. Von vier Kultivaren, die intensiv getestet wurden, war der Hauptunterschied, dass Cumulus ${ }^{\circledR}$ und Robin Hill im zwölften Jahr viel größer waren als Tradition ${ }^{\circledR}$ und Au- 
tumn Brilliance®. Cole's Select', 'Princess Diana', Reflection ${ }^{\mathrm{TM}}$, und Spring Glory® zeigten über sechs Jahre eine gute Performance, aber sie wurden auch nur an ein oder zwei Standorten getestet. Überleben, Wachstum und Gesundheit waren an geräumigen Standorten wunderbar, aber mit der richtigen Pflege können Felsenbirnen auch in der Innenstadt gut gedeihen. Alle acht Kultivare sind auch für Bepflanzungen unter Oberleitungen geeignet.

Resumen. A través del Programa Municipal de Restauración de Árboles los cooperadores plantaron ocho cultivares de cerezos (Amelanchier) en quince comunidades para la evaluación como árboles urbanos, comparando típicamente dos en cada comunidad. Mediciones estan- darizadas en los años 1, 2, 3, 6, 9 y 12 revelaron diferencias en el diámetro del tronco, altura, ancho de la copa, y salud del follaje y ramas. Entre los cuatro cultivares que han sido probados más extensivamente, la principal diferencia es que Cumulus ${ }^{\circledR}$ y Robin Hill son más altos en el $12^{\circ}$ año, que Tradition ${ }^{\circledR}$ y Autumn Brilliance ${ }^{\circledR}$. 'Cole's Select', 'Princess Diana', Reflection ${ }^{\mathrm{TM}}$, y Spring Glory ${ }^{\circledR}$ también ha respondido bien para los años seis y diez, pero solamente han sido probados en dos localidades. La supervivencia, crecimiento y salud han sido superiores en la mayoría de los espacios, pero con el cuidado apropiado los cultivares pueden desarrollarse bien en las calles del centro. Todos los ocho cultivares son apropiados para plantación bajo líneas aéreas. 